Mag. Daniela

Brečko

GV Izobraževanje

\title{
UČNA POGODBA - NOVO \\ ORODJE V IZOBRAŽEVANJU ODRASLIH
}

\section{Posameznik v središču učnega procesa}

\section{POVZETEK}

Učne sposobnosti posameznikov, organizacij in družbe postajajo daleč najpomembnejši dejavnik konkurenčne prednosti - na osebni, organizacijski in družbeni ravni. Osebna pričakovanja "delavcev znanja" na eni strani in potrebe organizacije na drugi strani pa vse bolj postajajo predmet pogajanj in temelj "psihološke" pogodbe. Učna pogodba je torej rezultat pogajanj med posameznikom in organizacijo o izpolnjevanju učnih ciljev. Posameznik sodeluje pri določanju učnih ciljev, virov in strategij, vodi učni oziroma izobraževalni proces in samostojno razpolaga z dodeljenimi finančnimi sredstvi.

Učna pogodba prinaša veliko koristi - tako posamezniku kot organizaciji omogoča, da se izobraževalni proces osredotoči na osebne potrebe učečega se, ki tako postane "lastnik" svojega izobraževalnega procesa in je zato tudi bolj motiviran, samostojen in odgovoren za rezultate učenja. Učenje pa je bolj načrtovano in strukturirano.

Učna pogodba je revolucionarna novost pri upravljanju znanja posameznika in organizacij, hkrati pa tudi novo sredstvo na kadrovskem področju za pridobivanje in razvoj talentiranih posameznikov.

Ključne besede: učna pogodba, izobraževanje, organizacije, samostojnost, individualní pristop

Vsi od odraslih pričakujemo, da bodo prevzeli odgovornost za svoj materialni in socialni položaj, za družino, za svoje zdravje in nenazadnje tudi odgovornost za svoj profesionalni in osebnostni razvoj. Od odraslih se skratka pričakuje, da bodo dosegali:

- biološko zrelost, ki pomeni fizično zrelost,

- psihološko zrelost, ki pomeni optimalno delovanje motorike in psihomotorike, sposobnost presojanja, nadzor nad čustvi, sposobnost abstraktnega mišljenja ...,

- socialno zrelost, h kateri prištevamo odgo- vornost za svoje ravnanje, vzdrževanje medosebnih odnosov, ravnotežje med sprejemanjem in dajanjem, lasten sistem vrednot, prilagodljivost ...,

- profesionalno zrelost, ki jo označujemo kot sposobnost za pravilno izbiro poklica in doseganje uspeha $v$ njem.

Vse naštete vrste zrelosti botrujejo razvoju določenih psihosocialnih značilnosti, ki korenito ločujejo odrasle od otrok. Iste psihosocialne značilnosti pa narekujejo tudi 
drugačen pristop $\mathrm{k}$ izobraževanju in usposabljanju odraslih. Ogledali si bomo štiri temeljne psihosocialne značilnosti odraslih in zahteve učnega procesa.

\section{PSIHOSOCIALNE ZNAČILNOSTI ODRASLIH IN ZAHTEVE UČNEGA PROCESA}

\section{Predstava odraslega o sebi}

Predstava o sebi (self image) kot posebna psihosocialna značilnost odraslih nastaja pretežno pod vplivom socialnega okolja. Začne se oblikovati že v rani mladosti, vendar je predstava o sebi pri otrocih izrazito dinamičen in fleksibilen pojav, ki jo otrok gradi le na osnovi reakcij drugih ljudi in se lahko spremeni tudi večkrat na dan. Predstava odraslega o sebi pa se oblikuje predvsem pod vplivom dveh dejavnikov:

- odnosov z drugimi ljudmi in

- dosežkov, pridobljenih z lastnim delom.

Pri odraslem človeku se torej predstava o sebi oblikuje pod vplivom tega, kar o njem mislijo in sodijo drugi in na temelju vrednotenja njegovih izdelkov - proizvodov njegove ustvarjalnosti. Nastaja kot zrcalna slika človeka obdajajočega sveta na človeka, njegove izdelke in dosežke. Predstava o sebi tudi pri odraslih ni stalen pojav, ampak se v Življenjskih obdobjih spreminja. Oblikujejo jo zlasti za posameznika pomembni življenjski dogodki in odnosi, ki jih vzpostavljamo $\mathrm{z}$ drugimi. Medosebni odnosi so izrazito dinamični, ves čas se spreminjajo in označuje jih velika stopnja subjektivizma. Slabi odnosi lahko zelo hitro porušijo človekovo predstavo o sebi. Če okolje posameznika ne sprejme, če nanj reagira izrazito negativno, bo pričel izgubljati samozavest, motivacijo in bo svoje aktivnosti v takšnem okolju bistveno zmanjšal. Pomembna značilnost oblikovanja pred- stave o sebi pri odraslem je tudi, da to ni več enosmeren proces. Kakšno mnenje bodo imeli drugi o nas, je odvisno tudi od naših odnosov $\mathrm{z}$ drugimi. Ves čas jim zavedno in nezavedno sporočamo, kako se počutimo, ali smo uspešni ali nas tarejo težave.

Oblikovanje predstave odraslega o sebi je torej proces vzajemnega vplivanja in delovanja posameznika in njegovega ožjega socialnega okolja. Odrasli imajo to moč, da tudi sami aktivno posegajo $\mathrm{v}$ oblikovanje predstave $\mathrm{o}$ sebi. $\mathrm{Na}$ eni strani $\mathrm{z}$ vzpostavljanjem pozitivnih in dobrih medosebnih odnosov $\mathrm{z}$ ljudmi, ki so zanje pomembni
Samopredstava odraslega se oblikuje $v$ procesu vzajemnega vplivanja.
- saj prav z odnosi lahko močno vplivajo na to, kaj bodo o njih mislili drugi -, po drugi strani pa je njihova predstava odvisna tudi od njihovih dosežkov.

Bistvena razlika med oblikovanjem predstave o sebi $v$ otroštvu in odraslosti je prav dvosmernost vplivanja in seveda moč odraslih, da to dvosmernost dosežejo in tako tudi aktivno posegajo $\mathrm{v}$ oblikovanje predstave o sebi ter jo na ta način, torej $\mathrm{z}$ aktivnim delovanjem, tudi spreminjajo $\mathrm{v}$ želeno in hoteno smer.

Predvsem je za učni proces odraslih bistvena velika kvalitativna razlika med otrokovo predstavo o samem sebi in njihovo predstavo. Otrok doživlja sebe kot odvisno bitje - biološko, eksistenčno, materialno, socialno in psihološko -, zato pričakuje zaščito in vodenje odraslih tudi v učnem procesu. Pričakuje, da ga bodo odrasli (starši, učitelji) poučevali, odločali namesto njega in reševali njegove težave.

Pri zreli odrasli osebi pa je predstava o sebi že popolnoma drugačna, saj je z mnoštvom vlog, ki jih je prevzel, pridobil veliko izkušenj, samostojnosti in zaradi vseh nakopičenih izkušenj spremenil predstavo o sebi. 
Prav zato pričakuje, da bo v učnem procesu enakovreden partner, učni proces si predstavlja kot dvosmerno komunikacijo, želi se znajti tudi v vlogi učitelja in ne zgolj učenca, noče nekritično sprejemati novih znanj, stališč in prepričanj, ampak želi novosti argumentirano preveriti $v$ medosebni interakciji z osebo, ki mu novo znanje posreduje (mentorjem, učiteljem, vodjem seminarja), želi izmenjati svoje izkušnje $\mathrm{z}$ drugimi in hkrati tudi vedno potrditi svojo predstavo o sebi.

\section{Identiteta odraslega}

Napačno je razmišljanje, da je pri odraslih identiteta za vedno oblikovana in odrasli ne doživljajo krize identitete. Resda je trdneje oblikovana, vendar pri odraslem problem identitete nastopi, ker si mora neprenehoma zagotavljati občutek in zavest kontinuitete kljub spremembam v lastnem življenjskem okolju, v različnih življenjskih okoljih, kljub razlikam med posameznimi dejavnostmi, ki jih opravlja, in kljub vsem drugim nenehnim spremembam okoli njega. Vsi ti pojavi neprestano rušijo posameznikovo identiteto in ker si njeno difuzijo težko privošči, si jo je prisiljen vedno znova graditi. Brez identitete si posameznik namreč močno oteži usklajevanje različnih perspektiv, s katerimi opazuje svet in samega sebe. Otežuje si tudi učenje in izobraževanje. Učenje je namreč vedno pot v neznano. Če ima posameznik močno identifikacijo, ve, kam se bo vračal na svoje področje delovanja, in na ta način ne bo ogrozil svojega notranjega ravnotežja.

Identiteta je ključno mesto za razumevanje osebnosti in osebnostnega razvoja. Posameznik se $v$ procesu osebnostnega razvoja počasi ločuje od pomembnih drugih in izoblikuje svojo lastno identiteto. V procesu razvoja posameznikove identitete ločujemo socialno in osebno identiteto. $\mathrm{Na}$ ravni izgrajevanja socialne identitete posameznik sprejme kulturni kod za matriko svojih dejanj. V socialni identiteti se izraža sposobnost posameznika, da se $\mathrm{v}$ različnih socialnih kontekstih vede stabilno in koherentno, v skladu s pričakovanji in prevladujočimi kulturnimi vzorci. Vzporedno s socialno identiteto se razvija tudi tako imenovana osebna identiteta, s pomočjo katere posameznik postavlja samega sebe $\mathrm{v}$ okvire določenega socialnega reda in prepoznava določene subjektivne in objektivne značilnosti, po katerih se razlikuje ali ne razlikuje od drugih oseb, npr. posebnost čutenja, mišljenja, delovanja. Prav izgradnja osebne identitete vtisne nezamenljivo osebno noto $\mathrm{v}$ posameznikovem socialnem delovanju.

Obstoj teh dveh identitet pomeni pomembno ločnico med otroštvom in odraslostjo. Med-

Pri učenju in izobraževanju, ki poteka $v$ skupini, se zato vedno pojavi potreba po identifikaciji v več smereh. Posameznik intenzivno išče svojo vlogo v skupini, hkrati pa skuša potrjevati svojo identiteto, kar povzroča intenzivno dinamiko interakcij. Iskanje identitete je pravzaprav sprožilni element skupinske dinamike, Proces poteka delno na zavedni, delno na nezavedni ravni. Na zavedni ravni se iskanje identitete odraža v tekmi za status v skupini. Dinamika interakcij pa teče tudi na nezavedni ravni. Vsakdo ima svoja pričakovanja, svoje predstave, svoje učne potrebe in svoje interese, za katere ne ve, ali jih bo lahko dosegel glede na številěnost skupine. Ali mu bo predavatelj, učitelj, svetovalec namenil dovolj pozornosti, da bo lahko uresničil svoje cilje? Izobraževalec odraslih naj bi zato pri delu uporabljal čim individualnejše metode dela in omogočil vsem udeležencem izobraževanja aktivno udeležbo in sodelovanje $v$ učnem procesu. V okviru opisanega namreč nastajajo in se razvijajo novi interesi osebe, oblikujejo se nova stališča, spreminja se vrednostni sistem, razvijajo se osebne karakteristike, skratka na ta način bomo dosegli cilj izobraževanja, ki ne more biti drugega kakor sprememba vedenja pri posamezniku. 
tem ko otroci izgrajujejo socialno identiteto in še ne ločujejo sebe od neposrednega socialnega konteksta, imajo odrasli $\mathrm{v}$ večji meri zgrajeno tudi osebno identiteto, torej lastno zavedanje sebe izven socialnega konteksta.

Odrasli so zaradi relativno trdno oblikovane osebne identitete nagnjeni $\mathrm{k}$ temu, da jo skušajo obvarovati tudi $v$ izobraževalnem procesu, ki pa je vselej deloma tudi pot $\mathrm{v}$ neznano.

\section{Izkušnje}

Odrasli imajo bogato zalogo izkušenj, ki so pomemben vir za reševanje problemov, hkrati pa jih prav to bogastvo izkušenj ločuje od otrok in mladine. Na malokaterem področju so odrasli povsem brez izkušenj. Izkušnje in navade pa zelo vplivajo na celotno človekovo vedenje. Na razum je treba gledati in ga razumeti kot zalogo znanja, ki si ga je posameznik pridobil $\mathrm{z}$ izkušnjami. $\mathrm{V}$ procesu socialne interakcije ljudje neprestano dodajajo svoji zalogi znanja novo znanje, ki ga pridobijo $\mathrm{z}$ novimi izkušnjami. Učenje je potemtakem proces, ki poteka ves čas, torej tudi takrat, kadar nismo v učilnici, kajti v smislu vseživljenjskega učenja je svet učilnica za vsakogar.

Odrasli razpolagajo z lastnim izkustvom, otroci pa še ne. Zaradi pomanjkanja lastnih izkušenj se otrok zateka k izkušnjam odraslih ljudi, uporablja torej sekundarno izkustvo. Tega pa ne zagovarja za vsako ceno, ker ga ni sam doživel. Izkušsnje odraslih so pridobljene $\mathrm{z}$ neposrednimi doživetji, zato je takšno izkustvo tudi krepko emocionalno obarvano. Odrasli se s svojimi izkušnjami identificirajo. Če njihovih izkušenj ne upoštevamo, jih prezremo ali celo zanikamo, kar pomeni napad na njihovo identiteto. $S$ tem lahko pri posamezniku sprožimo konflikt, ki se bo slej kot prej odrazil tudi v zunanjem okolju.

Pri izobraževanju odraslih je torej potrebno upoštevati izkušnje - tako izkušnje, pridoblje- ne $\mathrm{z}$ delom, kakor tudi razpršeno življenjsko izkustvo. Toda življenjsko izkustvo posameznikov se med seboj močno razlikuje, čeprav je morda njihovo delovno izkustvo podobno, zato je skorajda nemogoče, da bi izobraževalni program, četudi narejen po meri organizacije, zadostil vsem potrebam in izkušnjam udeležencev. Odrasli, ki se identificirajo s svojimi izkušnjami, se vedno znova čutijo ogrožene, če novega znanja
Ulčenje poteka ves čas, tudi takrat, ko nismo v učilnici. ne zmorejo povezati s prejšnjimi izkušnjami. Zaradi bogastva svojih pridobljenih izkušenj želijo odrasli te $v$ uěnem procesu tudi izmenjati, ne le $\mathrm{z}$ udeleženci, temveč tudi z učiteljem. Tudi sami želijo občasno prevzeti vlogo učitelja, kar zahteva dvosmernost komunikacije in seveda zelo učinkovito povratno informacijo.

Prav zato je $v$ izobraževalnem procesu še posebej pomembno, da v največji možni meri ugotovimo obstoječe izkušnje udeležencev izobraževanja, ne le delovnih, ampak tudi življenjske, jih upoštevamo pri programiranju oz. nastajanju učnih vsebin; to daje izobraževanju izrazito individualen pečat in nas praktično že navaja na rabo učne pogodbe, kot bomo videli v nadaljevanju.

\section{Samostojnost}

$\mathrm{V}$ andragoški teoriji je človekova samostojnost eden izmed glavnih elementov definicije in opredelitve tega, kdo je odrasel. Odrasli sebe dojemajo kot samostojno in neodvisno bitje $z$ vso družbeno odgovornostjo. To seveda dosežejo $\mathrm{z}$ ekonomsko in socialno osamosvojitvijo. Odtlej naprej posameznik gleda nase kot na človeka $\mathrm{z}$ lastno usmeritvijo. $S$ tem se spremeni tudi njegova predstava o sebi in skupaj $\mathrm{z}$ novo predstavo nastane $v$ njem potreba, da ga tudi drugi priznavajo kot samostojnega oziroma takšnega, kot se sam vidi, da je. 
Zahteva po priznanju samostojnosti odraslega torej bistveno ločuje od otrok. Potrebo po samostojnosti je treba upoštevati $v$ vseh medosebnih odnosih in socialnih razmerjih $\mathrm{z}$

\section{Priznavanje} samostojnosti je potreba odraslih. odraslimi, še posebej pa v učnem procesu. Po drugi strani pa tudi odrasli iščejo in vstopajo $\mathrm{v}$ takšne socialne interakcije, kjer lahko to potrebo zadovoljijo. To pomeni, da so za osebnostni razvoj odraslih ugodna le tista socialna okolja, ki dopuščajo samoiniciativnost, samostojnost pri delu, izražanju notranjih stanj in pri sprejemanju odločitev.

Učni proces, kamor štejemo tako vzgojo kakor izobraževanje, je prav tako socialna interakcija. Kar se tiče učinkovitosti učenja, je še posebej pomembno, da upoštevamo potrebo odraslih po priznavanju samostojnosti in neodvisnosti in ravnamo $\mathrm{z}$ njim $\mathrm{v}$ skladu s tem spoznanjem, sicer utegnejo pri posameznikih nastati škodljive posledice za učenje. Vzgojni in izobraževalni učinek je minimalen, tvegamo upad motivacije in celo trajen odpor do izobraževanja. Odrasle odbija predvsem to, da so potisnjeni $v$ podrejeno vlogo in v otročji položaj.

\section{PSIHOSOCIALNE POTREBE NAREKUJEJO NOVA ORODIA - UČNO POGODBO}

Učna pogodba kot novo orodje učnega procesa se je razvila na številnih predpostavkah o naravi odraslega učenca in vodenja učnega procesa. Za idejnega očeta učne pogodbe lahko upravičeno štejemo pedagoga Malcolma Knowlesa, ki je prepričan, da bi bilo treba odrasle učence kot samostojne ljudi spodbujati, naj prevzamejo več odgovornosti za svoje učenje in uporabijo že pridobljene spretnosti in izkušnje kot podlago za novo snov, Knowles se je na začetku svoje kariere zelo veliko posvečal odraslim študentom, ki

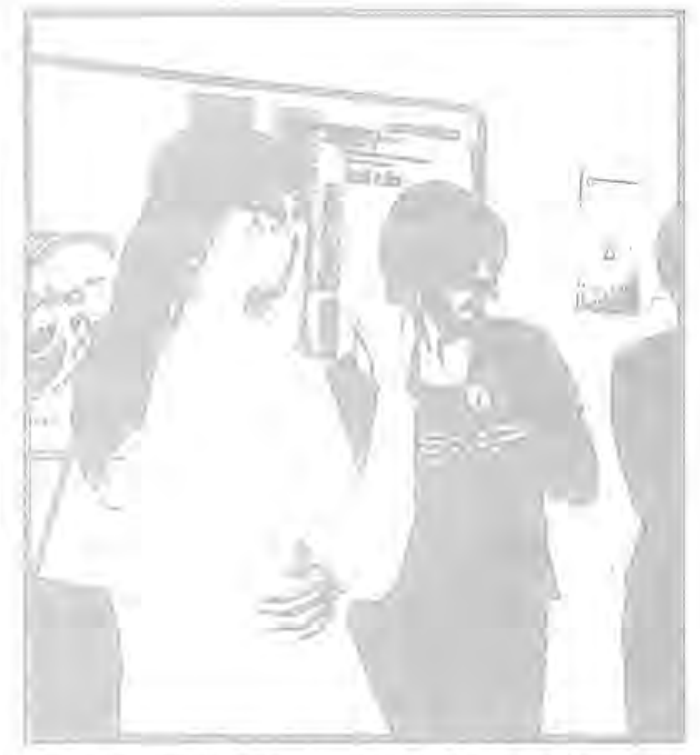

so se izobraževali ob delu, zato se je koncept učne pogodbe uveljavil najprej $\mathrm{v}$ ustanovah za terciarno izobraževanje in $\mathrm{v}$ izobraževalnih organizacijah za odrasle (poslovnih šolah, ljudskih univerzah ...), dandanes pa se je uporaba učnih pogodb razširila celo v osnovne in srednje šole, predvsem $v \mathrm{ZDA}$ in Angliji, najpogosteje pa jo uporabljajo pri poklicnem usposabljanju in izobraževanju ter pri načrtovanju in razvoju kadrov v številnih organizacijah.

Izobraževalni pristopi, pri katerih uporabljamo učne pogodbe, se odmikajo od tradicionalnega odnosa med učiteljem in študentom ter od predavalnice $\mathrm{v}$ svet, $\mathrm{v}$ katerem ljudje živijo in delajo. Ti pristopi so nastali kot odziv na širši družbeni kontekst in spremembe družbenih vplivov, Izobraževanje je bilo zadnja leta vedno predmet kritičnih razprav in vročih polemik, kjer so se iskali učinkovitejši načini za pridobivanje znanja. Največji očitki izobraževalnemu sistemu pa so se zgrnili na uporabo naučenega, izkoristek je (bil) mnogo premajhen. Očitno so ti dejavniki privedli ljudi, ki se ukvarjajo z izobraževanjem, h kritičnemu ovrednotenju njihovih učnih pristopov in $\mathrm{k}$ iskanju alternativ. Če je še pred nekaj leti študent pomenil 
"le številko", postaja danes učeči se posameznik vse bolj središče učnega procesa. V nekaj alineah lahko izluščimo glavne dejavnike, ki so soustvarili okolje za kritični premislek:

- vse večja udeležba študentov zrelih let in drugih netipičnih študentov $v$ izobraževalnem procesu,

- večje število izobraževalnih programov, ki kot pomemben element vključujejo delovne izkušnje,

- številne institucionalne in prostovoljne pobude, ki spodbujajo aktivno, izkušenjsko in sodelovalno učenje,

- zahteve posameznikov po sodelovanju prí oblikovanju izobraževalnih programov,

- premik od prenašanja znanja ( $\mathrm{z}$ učitelja na študenta) na prenašanje izkušenj,

- veliko polemik v zvezi s sodelovanjem gospodarstva pri formalnih izobraževalnih programih,

- zahteve delodajalcev po diplomantih, ki imajo več spretnosti s področij komunikacije, medosebnih odnosov in reševanja problemov,

- povečano število posameznikov, ki se izobražujejo v vseh sektorjih gospodarstva in negospodarstva,

- Živahno trženje izobraževalnih programov,

- splošno družbeno pričakovanje, da bi morali ljudje imeti več besede (se udeleževati in posvetovati) pri odločitvah, ki zadevajo njihov razvoj.

Še bi lahko naštevali, toda že iz opisanih dejavnikov je več kot očitno, da se udeleževanje ljudi $v$ družbenem in političnem življenju povečuje. Ljudje želijo sodelovati v procesih razvoja družbe, predvsem pa želijo imeti nadzor nad lastnim izobraževanjem in življenjskimi odločitvami.

Prav zato je več kot nujno, da izobraževalne institucije, bodisi da gre za univerze, zasebne izobraževalne organizacije ali izobraževalne centre $\mathrm{v}$ podjetjih, ponudijo posamezniku priložnost, da prevzame odgovornost in nadzor nad lastnim izobraževalnim procesom. To pomeni, da morajo učitelji/ predavatelji/svetovalci in izobraževalne ustanove $\mathrm{v}$ prihodnosti pogosteje vnašati učne pogodbe $v$ svoje programe. Njihova uporaba je v poslovnem svetu že dodobra zakoreninjena, posebno pri razvoju vodstvenih kadrov in
Učna pogodba je odgovor na iskanje ucinkovitejših načinov izobraževanja. pospeševanju delovne učinkovitosti.

\section{KAJ JE UČNA POGODBA?}

Do sedaj smo že veliko povedali o nujnosti uporabe učnih pogodb, nismo pa še jasno definirali, kaj je učna pogodba.

Na prvi pogled se mogoče zdi, da ta pristop predstavlja revolucionarno orodje, $\mathrm{ki}$ je povsem $v$ nasprotju $\mathrm{s}$ tradicionalnim učnim procesom, pri katerem se posamezniki udeležijo izobraževalnega programa $\mathrm{z}$ namenom, da bi si pridobili novo znanje, predavatelj ali učitelj pa je kot strokovnjak za svoj predmet tisti, ki določi, kaj in kako se bodo učili. Toda učno pogodbo je brez posebnih naporov mogoče uporabiti tudi
Udeležba ljudi v političnem življenju se povečuje, kaj pa v izobraževanju? pri tradicionalnih formalnih programih, ki temeljijo na predavanjih, predstavitvah $\mathrm{v}$ razredu, predpisanih nalogah in uradnih izpitih. Učna pogodba je $v$ takšnih primerih uporabna predvsem kot koristen dodatek drugim metodam poučevanja in ocenjevanja, predvsem pa z njo opogumimo posameznike za bolj poglobljeno učenje.

Velika prednost učne pogodbe je predvsem njena prožnost. Kot bomo videli $v$ nadaljevanju, je mogoče učno pogodbo prilagoditi 
Učna pogodba je dokument, s katerim si pomagamo pri načrtovanju izobraževalnega procesa oz. študijskega projekta. To je pisni dogovor, $v$ katerem se študent in učitelj, predavatelj ali svetovalec dogovorita za potek procesa in se skupaj odločita, čemu je izobraževanje sploh namenjeno - kakšnemu oz. katerim učnim ciljem.

tako rekoč vsem izobraževalnim področjem in vsem vrstam usposabljanja vsaj $\mathrm{v}$ enem delu programa.

Učna pogodba je $v$ bistvu "učni načrt". Uspešna podjetja sklepajo učne pogodbe z "delavci znanja". Omogoča nam, da se pri oblikovanju učne dejavnosti osredotočimo na posamezni$\mathrm{ka}$ in ne toliko na vsebino oz. učitelja. Zaradi te svoje značilnosti so učne pogodbe še posebej primerne za:

- projektni način učenja/projektno delo, kjer bo posameznik učno snov obdelal precej samostojno,

- programe, katerih udeleženci imajo zelo različno poprejšnjo izobrazbo,

- akcijsko učenje, ki mora pokazati takojšnje rezultate $\mathrm{v}$ praksi,

- oblikovanje daljših individualnih razvojnih izobraževalnih načrtov,

- individualno učenje "po meri", časovno krajše, prilagojeno posameznikovim potrebam in zanimanju,

- individualno svetovanje.

Sicer pa je moč $\mathrm{z}$ malo spretnosti učno pogodbo prenesti v katerokoli učno okolje.

\section{UČITELJ/PREDAVATELJ/KADROVIK VSE BOLJ POSTAJA SVETOVALEC}

Učna pogodba omogoča, da učeči se posameznik tvorno sodeluje že $v$ procesu ugotavljanja potreb in pri določanju učnih strategij in virov. Gre torej za nekakšen

dogovorjeni sporazum o tem, kaj in kako se bo posameznik učil in kako bo naučeno dokazal na koncu izobraževalnega procesa. Takšen dogovor je lahko vedno le rezultat določenih pogajanj in zahteva zavezanost vsaj dveh strank - učečega se posameznika in osebo, ki tako ali drugače prevzame skrb nad izobraževanjem. Ta je lahko vodja izobraževanja ("knowledge manager") oz. referent za izobraževanje ali kadrovski menedžer oz. kadrovski referent $v$ organizaciji, v manjših podjetjih pa tudi sam direktor, še posebej kadar uěno pogodbo uporabljamo za razvoj vodstvenega potenciala in načrtovanje vodilnih delovnih mest.

Že uvodoma smo zapisali, da je učna pogodba učinkovito sredstvo načrtovanja učnega procesa odraslih tudi $\mathrm{v}$ formalnih izobraževalnih programih za odrasle. Vlogo pogajalca $\mathrm{v}$ srednješolskih in visokošolskih ustanovah za odrasle lahko tako prevzame koordinator programov, predavatelj enega od predmetov, mentor, učitelj, inštruktor ali organizator. Delovnih vlog, ki lahko nastopijo v vlogi pogajalca pri sestavljanju učne pogodbe, je torej precej. V vsakem primeru pa mora vsakdo, ki nastopi v tej vlogi, odigrati vlogo svetovalca, zato bomo $\mathrm{v}$ nadaljevanju za vse te vloge uporabljali izraz "svetovalec".

$\mathrm{V}$ tretjem poglavju, kjer govorimo o implementaciji učne pogodbe $v$ organizacijo, bomo $v$ ta namen še bolj podrobno osvetlili vlogo menedžerja svetovalca pri razvoju zaposlenih.

Pogajanje o izobraževanju se ponavadi začne $s$ pogovorom o vlogah, odgovornosti in pričakovanjih obeh strank. Kadar govorimo o izobraževanju zaposlenih, je vsekakor jasno, da imajo svoje potrebe tako organizacije kot tudi posamezniki. Četudi želi organizacija zadostiti novim izobraževalnim potrebam s tem, da načrtuje izobraževanje dveh ali več posameznikov, se bodo dejanske izobra- 
ževalne potrebe odrazile šele $\mathrm{v}$ skrbnem pogovoru s posamezniki, saj le-ti določeno znanje že imajo. Dejanski manko znanja je torej odvisen od posameznikove prejšnje izobrazbe, izkušenj, razvite stopnje spretnosti ... Prvi pogovori in prva pogajanja pri sestavi učne pogodbe se zato pričnejo $\mathrm{z}$ določitvijo učnih ciljev in ugotavljanjem izobraževalnih potreb, nadaljujejo s pogajanji o tem, kako naj bi učni proces potekal in kakšne rezultat naj bi prinesel. Pri tem posameznik prevzame odgovornost za to, da opravi izobraževalne aktivnosti, za katere se je dogovoril, svetovalec pa za to, da ga ustrezno podpre in poskrbi, da posameznik izpolni zahteve programa. Gre torej za klasičen proces pogajanja, iskanja soglasja in sklenitev sporazuma.

\section{ODGOVORNOSTI SVETOVALCA PRI UČNI POGODBI}

Svetovalec in posameznik se morata torej sporazumeti glede učnih ciljev, učne strategije, virov, rezultatov ... Za uspešen potek tega pogajalskega procesa se nujno zahteva tvoren odnos med obema strankama, ki mora temeljiti na odprti komunikaciji in določeni stopnji medsebojnega spoštovanja. Prav tu se lahko pojavijo prve težave, zlasti kadar bodisi posameznik bodisi svetovalec nimata dovolj razvitih spretnosti komuniciranja ali prihajata iz okolij, ki imata različno kulturno matriko izražanja, npr. posameznik prihaja iz izrazito tehničnega okolja, svetovalec pa iz izrazito družboslovnega. V takšnih primerih je priporočljivo, da se najprej pogovorita o študentovem referenčnem okviru in namesto izpolnjevanja zahtev programa preneseta poudarek na zadovoljevanje učnih potreb, pri čemer mora svetovalec ohranjati pravo smer, opozarjati na bistvo (učni cilj) in ohranjati izobraževalne standarde. Koliko podpore in nasvetov bo lahko ponudil posamezniku, je v največji meri odvisno od njegove strokovne usposobljenosti in razpoložljivih virov ter drugih izobraževalnih dejavnikov.

Če želimo, da bo učna pogodba uspešna, mora svetovalec spodbujati dialog med samim potekom učne pogodbe. $V$ teh razgovorih mora imeti posameznik možnost pridobiti povratno informacijo o tem, kaj se je že naučil, in se pogovoriti o prihodnjih smernicah. Ves čas trajajoče spremljanje in podpora sta najpomembnejši aktivnosti svetovalčeve vloge. Vedno moramo imeti $v$ mislih tudi dejstyo, da je posameznik podpisnik učne pogodbe in torej enakovreden partner $\mathrm{v}$ učnem procesu, kar bi $\mathrm{z}$ drugimi besedami pomenilo,
Uǐna pogodba omogoća lastnišvo nad učnim procesom. da mora "lastništvo" nad učnim procesom zaživeti $v$ polnem pomenu te besede. Posameznik ne sme dobiti občutka, da mu svetovalec le nalaga izobraževalne aktivnosti, on pa se z njimi zgolj strinja. Svetovalec mora med potekom učne pogodbe skrbno ohranjati ravnotežje, pri čemer mora biti njegov cilj ta, da postavlja posamezniku nove izzive, širi njegove meje, podaja povratno informacijo, izrazi zadovoljstvo, če se je naučil nekaj novega ali se izuril v novih spretnostih. Tovrstne aktivnosti svetovalca navadno presegajo zgolj začrtan okvir predmeta in zajemajo tudi komunikacijo, organizacijo, upravljanje $\mathrm{s}$ časom in motiviranje, prenašanje izkušenj, prenašanje naučenega v prakso itn.

Posamezniki imajo le redko enake cilje, zato je svetovalčeva vloga pri učni pogodbi še pomembnejša kot pri klasičnih oblikah učenja. Ves čas skrbi za skladnost med posameznikovimi potrebami, željami in zahtevami izobraževalnega programa oz. cilji. Njegova vloga je torej motivacijska, spodbujevalna in hkrati tudi kritična in ocenjevalna.

Če povzamemo, je učna pogodba dogovor/sporazum, ki nastane na podlagi pogajanj 
med posameznikom in svetovalcem in temelji tako na učnih potrebah posameznika kot tudi na formalnih zahtevah izobraževalnega programa oziroma organizacije, kjer se izobražuje. Je učni načrt, ki opredeljuje tudi pričakovane rezultate in način njihovega preverjanja. Pri tem je zlasti pomembno, da učna pogodba odraža visoko stopnjo fleksibilnosti in jo lahko prilagodimo potrebam vsakega učečega se posameznika.

\section{SESTAVNI DELI UČNE POGODBE}

Učno pogodbo sklenemo v obliki obrazca, ki se lahko razlikuje od programa do programa in od posameznika do posameznika.
Razlikuje se glede na učne cilje, načine doseganja teh ciljev, virov in končnih rezultatov.

Poleg teh štirih temeljnih elementov ima učna pogodba seveda tudi vse ostale elemente kot druge pogodbe: opredeljen je čas trajanja pogodbe (datum začetka in konca izobraževalnega programa) in tudi konkretne sposobnosti ali področja, ki jih želimo z učno pogodbo razviti. Ko se posameznik in svetovalec strinjata glede vseh podrobnosti, dokument podpišeta in obdržita vsak po en izvod. Na sliki 1 je prikazan najbolj razširjen obrazec za pripravo učne pogodbe.

Kot stranski proizvod pogajanj lahko dobimo veliko pripomb in predlogov, ki sicer sami po

\section{Slika 1: Predlog obrazca za učno pogodbo}

\section{UČNA POGODBA za:}

Ime in priimek študenta

Delovno mesto

Dosedanja izobrazba

Število let delovne dobe

Aktivnost/izobraževalni program

Predmet/tema ali področje

Svetovalec

Začetek projekta Rok za oddajo

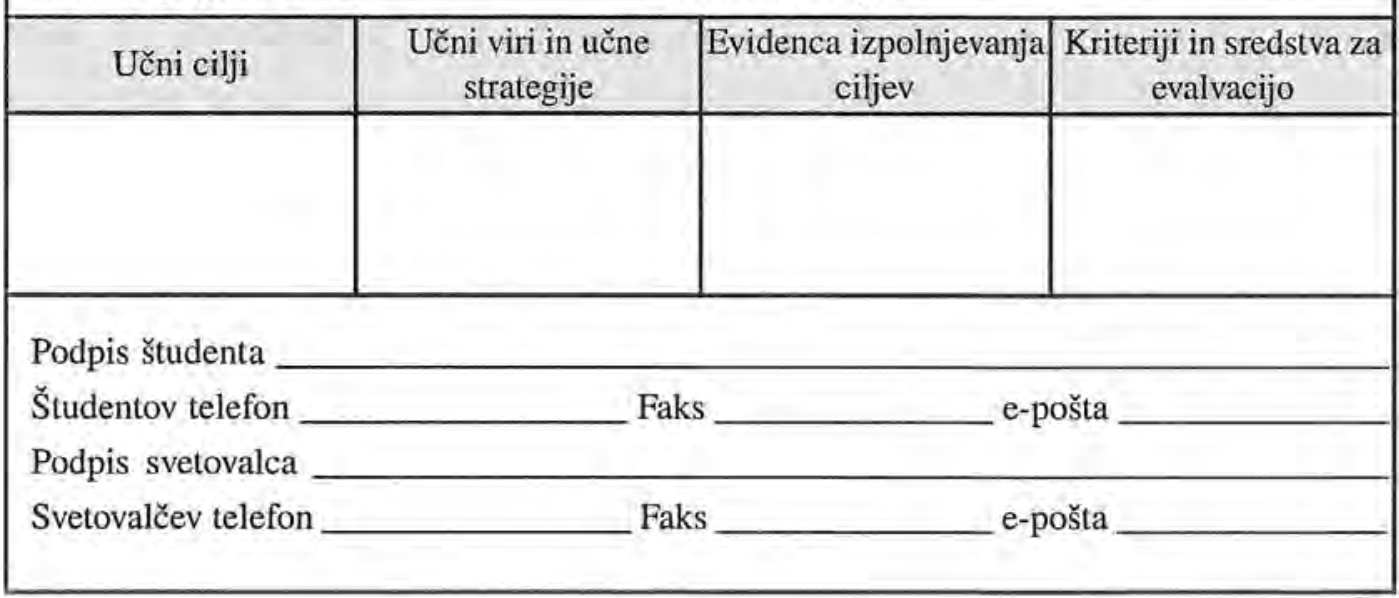


Na splošno je vsaka učna pogodba razdeljena na štiri ločene dele, ki se morajo podrobno opredeliti:

- učne cilje izobraževalnega programa/projekta,

- učne strategije in učne vire, ki so na voljo za dosego učnih ciljev,

- dokaze, kdaj bo posameznik te cilje dosegel,

- kriterije, s pomočjo katerih bomo vedeli, ali je posameznik cilje dosegel ali ne,

sebi niso predmet učne pogodbe, velikokrat pa lahko svetovalcu in posamezniku koristijo pri poteku učnega procesa. Zato imajo nekatere pogodbe poseben razdelek, kamor lahko svetovalec zapiše pripombe, prav tako pa tudi posameznik ključne točke, ki so se pokazale med pogovorom.

Nemalokrat se med samim potekom izvajanja pokaže potreba po ponovni določitvi učnih ciljev, učne strategije ali virov, kar pomeni, da se znova vrnemo na izhodišče in se je treba torej ponovno pogajati glede izvirne pogodbe. Svetovalec in posameznik lahko $\mathrm{v}$ takšnih situacijah oblikujeta in parafirata dopolnila in predelave že obstoječe pogodbe, ki ostaja izvirni dokument, pri čemer je spet pomembno, da se posameznik in svetovalec strinjata glede vseh novosti in sprememb, preden jih vneseta $\mathrm{v}$ učno pogodbo.

Uspeh učne pogodbe se največkrat presoja glede na to, kako se je posameznik približal učnim ciljem, ki sta jih s svetovalcem skupaj določila, zato je nenazadnje potrebno tudi jasno opredeliti, kdo bo preverjal rezultate učne pogodbe in po kakšnih kriterijih jih bo ocenil.

\section{FLEKSIBILNOST DA, TODA NE LAISSEZ FAIR}

Učna pogodba je zagotovo eno izmed najprilagodljivejših orodij za načrtovanje učnega procesa, ki dopušča posamezniku, da aktivno sodeluje $\mathrm{v}$ tem procesu. Toda zmotno je prepričanje, da je $\mathrm{v}$ učni pogodbi vse dovoljeno. Poskušajmo si predstavljati dalji- co, ki ima na enem koncu do potankosti predpisano, na drugem pa popolnoma samostojno učno aktivnost, ki jo študent sam usmerja. Učne pogodbe ne moremo uvrstiti ne na en, ne na drug konec daljice, temveč nekje na sredino. Lahko bi jo primerjali s projektnim načrtom, ki se prilagaja njegovim izvajalcem, $v$ našem primeru posamezniku, ki se bo izobraževal. Pri tem mora načrt večkrat upoštevati precej stroge parametre, ki so včasih lahko precej togi in jih določa svetovalec kot predstavnik organizacije. Sodobne prakse izobraževanja odraslih uporabljajo učno pogodbo kot učni načrt in hkrati kot sredstvo za ocenjevanje in vrednotenje pridobljenega znanja.

Učne pogodbe ni mogoče uporabljati pri povsem samostojnem učenju, saj že sama definicija samostojnega učenja ne dopušča pogajanj glede učenja, temveč predpostavlja, da si bo posameznik sam izbral učni cilj in si sam postavil dokaze za izpolnjevanje učnega cilja. Pri popolnoma samostojnem učenju dejavnik vrednotenja lahko celo manjka, saj ni tako pomemben, ker postane najpomembnejše merilo za uspeh posameznikovo zadovoljstvo (Caffarella in O'Donnell, 1991).

Tisti, ki imajo izkušnje s pogajanji, trdijo, da je prav pripravljenost na kompromis bistvenega pomena za uspešen sporazum in zavezo, da ga bomo izpolnili, vendar pa obstajajo tudi točke, o katerih se ni moč 
V učni pogodbi se določijo cilj in tudi sredstva za dosego tega cilja. Cilj je pridobitev novega področja spretnosti ali znanja, novo, primernejše vedenje, ki ga želi organizacija razviti pri posamezniku. Učna pogodba vselej predpostavlja, da $v$ njej sodelujeta vsaj dva človeka, kjer se je vsaka stranka pripravljena odpovedati nekaterim ugodnostim $\mathrm{v}$ zameno za druge. Posameznik ima sicer neprimerno več nadzora nad svojim izobraževalnim procesom kot $\mathrm{v}$ tradicionalnih akademskih pristopih, toda še vedno ostajajo področja, ki niso odprta za pogajanja.

pogajati in popuščati. Definiranje elementov, o katerih se je mogoče pogajati, in tistih, o katerih se ni, je potemtakem pomembna faza pri oblikovanju ustrezne učne pogodbe. Področje, o katerem se ni moč pogajati, je ponavadi povezano $\mathrm{z}$ merili ocenjevanja in tistimi elementi učne pogodbe, ki veljajo za vse udeležence določenega programa.

Ena od pomembnih nalog svetovalca je torej tudi ta, da poskrbi, da učna pogodba zadovolji organizacijske/akademske zahteve in je primerno stroga, kar $v$ aktivnostih svetovalca pomeni, da se mora s posameznikom že na začetku temeljito pogovoriti o vrstah podpore in mejah svobode.

\section{RAZLIKA MED UČNO POGODBO IN DELEGIRANIM IZOBRAŽEVANJEM}

V želji, da bi čimbolj osvetlila koncept učne pogodbe, $v$ nadaljevanju podajam tudi razliko

Učna pogodba

opredeljuje tako

načrt uicenja kot

tudi njegovo ovrednotenje. med učno pogodbo in delegiranim izobraževanjem. Zakaj ravno ta primerjava? V nekaterih organizacijah je praksa, da posameznika pošljejo na določeno izobraževanje, pri tem pa nima pravice ugovarjati in kako drugače sodelovati pri odločitvi. V tem primeru bi lahko rekli, da gre za prisilno napotitev na izobraževanje oziroma delegirano izobraževanje. Med učno pogodbo in delegiranim izobraževanjem obstaja pomembna razlika. $\mathrm{V}$ nasprotju $\mathrm{s}$ slednjim je učna pogodba dokument, ki temelji na razpravi in skupnih odločitvah. Pogodba je odprta za ponovno pogajanje, če se okoliščine spremenijo. Posamezniki, ki se prvič srečujejo $\mathrm{z}$ učno pogodbo, so ponavadi precej zaskrbljeni, ali jo bodo sestavili "pravilno", ali se bodo dobro spogajali. Na učno pogodbo moramo gledati kot na živ dokument in ne kot na nespremenljivo obvezo, saj se tako izognemo mnogim začetnim bojaznim.

Učno pogodbo uporabljamo tako za opredelitev učnega načrta kot tudi za ovrednotenje izobraževalnega programa, zato ni vselej jasno, čemu služi. Ali učno pogodbo uporabljati predvsem kot alternativno učno strategijo ali kot metodo ocenjevanja? Svetovalcem in posameznikom, ki bodo učno pogodbo uporabljali, mora biti jasno, kakšsen je namen pogodbe in kako daleč lahko sežejo njene uporabne koristi znotraj aktivnosti konkretnega izobraževalnega programa. Na primer: za dokončno oceno posameznikovega znanja določene vsebine včasih ni dovolj le izpolnjevanje kriterijev učne pogodbe, ampak bo potrebno predložiti Še druge dokaze, kot je recimo stopnja napredka na podlagi diagnostičnih testov, kar je še posebej v rabi pri vodstvenih razvojnih programih.

Pri prvi predstavitvi učne pogodbe je posameznikom priporočljivo opredeliti razlike med učno pogodbo in vnaprej določenim/ delegiranim izobraževanjem ter razložiti prednosti tovrstnega pristopa, ki se kažejo predvsem $v$ večji motiviranosti in odgovornosti za posameznikov lastni izobraževalni proces. Če je učna pogodba posameznikom relativno neznana, je morda bolje, da se njene uvedbe lotimo postopoma. $\mathrm{Z}$ njo lahko dopolnimo posamezni razvojni program, oziroma jo uporabimo le za določen izobraževalni program. Ne glede na to, da lahko učno pogodbo uporabimo pri enem izobra- 
ževalnem programu, pa se pogodba vselej oblikuje na podlagi analize posameznikovih učnih potreb in premisleku o najboljšem načinu za izpolnitev teh potreb. Če menimo, da recimo dokaz o izpolnitvi učne pogodbe, kot je pisanje eseja ali poročila, ni pretirano koristen, lahko raziščemo druge možnosti. Učna pogodba omogoča torej precej svobode in prožnosti pri določanju, kaj je treba predložiti v ocenjevanje in kako priti do tega izdelka oz. kako izpolniti učno pogodbo.

\section{IZPOLNITEV UČNE POGODBE - INDIVIDUALNI REZULTATI PRED SKUPNIMI}

O splošnih rezultatih učne pogodbe je težko govoriti in tudi ni namen učne pogodbe, da bi dajala splošne rezultate. Njen namen je $v$ tem, da daje zelo individualne rezultate, $V$ istem izobraževalnem programu se en posameznik v učni pogodbi obveže, da bo napisal oceno knjige, drugi pa kritiko televizijskega programa. Dolžina prispevka lahko niha od eseja s petsto besedami do poročila s pet tisoč besedami ali pa je obseg poročila prepuščen posameznikovi odločitvi in $\mathrm{v}$ pogodbi ni zapisanih posebnih omejitev. Prav tako je lahko vsebina učne pogodbe omejena le na teme določenega izobraževalnega programa, lahko pa določa še druge teme ali predstavlja izhodišče za povsem samostojen študij.

S pomočjo neodvisne učne pogodbe imajo posamezniki možnost, da raziščejo tudi področja zunaj predpisanih vsebin izobraževalnega programa ali individualiziranega projekta. V takšnih primerih imajo posamezniki dokaj proste roke, da izberejo teme v skladu s svojimi trenutnimi interesi. Seveda se pričakuje, da se bo učna pogodba nanašala na potrebe organizacije oz. cilje formalnega izobraževalnega programa.

Pri izbiri dokazov za izpolnjevanje pogodbe posamezniki izberejo pisanje eseja ali poročila. $\mathrm{V}$ pogajalskem procesu pa lahko svetovalec od njih zahteva tudi zahtevnejše dokaze, kot je samostojno delo na določenem področju, samostojna izvedba projekta oz. določene naloge. Če se recimo posameznik usposablja za vodenje letnega razgovora, je lahko dokazilo o izpolnitvi učne pogodbe samostojna priprava obrazca za
Uína pogodba je orodje za izpopolnjevanje individualnih izobraževalnih potreb. vodenje letnega razgovora, $v$ praksi izveden letni razgovor in ocena vodenja letnega razgovora s strani tistih, s katerimi je letni razgovor izvedel.

\section{POGODBEN ODNOS SPODBUIA MOTIVACIJO ZA IZOBRAŽEVANJE}

Bistvena prednost učne pogodbe je v tem, da spodbuja poglobljen pristop $\mathrm{k}$ učenju (Marton in drugi, 1984). Dobro pripravljena učna pogodba posameznika spodbudi $\mathrm{k}$ temu, da se ne ustavi pri nabiranju znanja o predpisani vsebini, temveč začne razmišljati, kako bi lahko pridobljeno znanje uporabil v praksi, kako uspešno je bilo njegovo dosedanje učenje in kako lahko načrtuje svoje izobraževanje v prihodnosti. Pogodben odnos spodbudi posameznika, da pretehta svoja načela, prepričanja in zmožnosti, da poglobljeno

Cilj učne pogodbe je v osredotočanju na izdelek, proces ali reflektivno evalvacijo (Russell in drugi, 1994). Ponavadi cilj sestavljajo vse tri komponente, vsaka je poudarjena $v$ določeni fazi, ki so zajete $v$ pogodbi. Tako posameznik in svetovalec skupaj oblikujeta izobraževalno izkušnjo. Namesto da bi posameznik pasivno sprejemal znanje, je prisiljen prevzeti bolj dejavno in aktivno vlogo, s katero se nujno tudi osebno identificira. V praksi se je praviloma izkazalo, da ko enkrat posameznik prevzame osebno pobudo za učni projekt, se tudi zelo poveča verjetnost, da bo njegovo učenje globlje in trajnejše, rezultati pa boljši in dolgotrajnejši. 
razmišlja o svojem izobraževalnem in razvojnem procesu ter $v$ njem sodeluje. Pogodba je torej povsem jasna glede vsebine, ki jo je treba preštudirati, vendar je $\mathrm{v}$ njej vselej tudi element "bolj subtilnega dogovora glede vrednot, predpostavk in idealov" (Hansen, 1991, str. 123).

Učno pogodbo lahko sicer uporabljamo pri večini izobraževalnih programov, njena uporabnost pa zažari v vsem svojem bogastvu pri tistih izobraževalnih programih, ki vsebujejo praktično sestavino. To so na primer programi usposabljanja, ki vključujejo delovne izkušnje, problemsko učenje, akcijsko učenje, razvijanje določenih spretnosti ... Učna pogodba namreč daje posamezniku proste roke, dovoljuje mu, da si sam organizira učne vire, sam poišče in izbere učne priložnosti, ki so mu na voljo, in tako zadovolji določeno učno potrebo. Posameznik tako dejavno raziskuje možnosti za učenje $v$ situacijah, ki bi jih sicer izobraževalni program spregledal ali pa spričo togosti ne mogel izkoristiti.

\section{ZAKAJ UPORABLJATI UČNO POGODBO?}

Učna pogodba $v$ Sloveniji velja za precej inovativen pristop $\mathrm{k}$ učnemu projektu ali dopolnilo formalnemu študiju. Ideja in koncept učne pogodbe sta bila prvič predstavljena leta 2001 v okviru Dnevov kadrovskih delavcev, ki jih vsako leto tradicionalno organizira podjetje GV Izobraževanje. Ko ljudje prvič slišijo za to idejo, so naravno radovedni, kaj to je in kakšne koristi bi imeli, če bi uporabljali učne pogodbe ter tudi, kako jih razviti v praksi.

Koristi so lahko, kot sem že predstavila na predhodnih straneh, pri vsakem posamezniku drugačne. Kljub vsemu pa lahko na podlagi osebnih izkušenj pri rabi učne pogodbe in izkušenj strokovnih kolegov iz tujine, ki smo

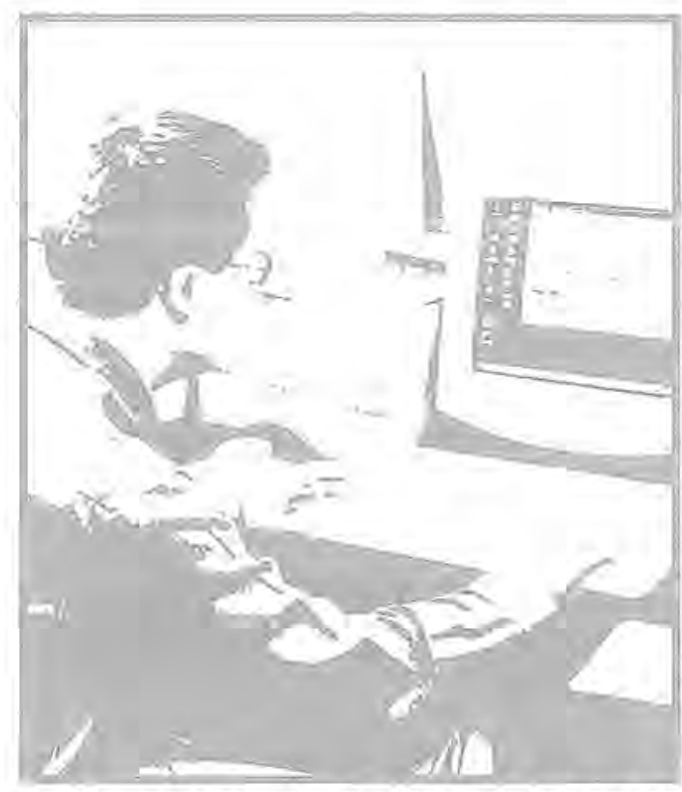

si jih pridobili na najrazličnejših študijskih področjih, povzamem štiri razloge za uporabo učne pogodbe.

\section{VEČJA MOTIVIRANOST}

Učna pogodba dosledno upošteva razlike med posamezniki in omogoča, da se izobraževalne aktivnosti prilagodijo konkretnim potrebam in interesom posameznika na eni strani in organizacije na drugi strani. $\mathrm{Z}$ učno pogodbo usklajujemo in uravnotežimo posameznikove osebne potrebe $\mathrm{z}$ zahtevami podjetja oz. izobraževalne institucije. Posamezniki sami definirajo svoje izobraževalne potrebe, sami torej ugotovijo in določijo primanjkljaj, zato se jim praviloma vse izobraževalne aktivnosti, ki so seveda odraz teh potreb, zdijo smiselnejše, bolj življenjske in zanimivejše. Motivacija in zavezanost bosta zato večji kakor pri tradicionalnih učnih strategijah. Posameznik postane (so)lastnik svojega izobraževalnega procesa, sprejme ga za svoj cilj, zunanjo motivacijo spremeni v notranje gonilo.

Pri poklicnem usposabljanju in pri dodatnem izobraževanju lahko uporabimo učno po- 
godbo za razvijanje specifičnih spretnosti in zmožnosti, potrebnih za posameznikovo delovno okolje ali prakso. Učna pogodba namreč upošteva in gradi na že pridobljenih spretnostih in izkušnjah, ki jih dodatno razvija, pri tem pa prepoznava povezave in medsebojne učinke. Tako postane študij neposreden, veliko bolj praktičen, pridobljeno znanje pa uporabnejše. To posameznika še dodatno motivira za upravljanje učnega procesa in napredovanje $\mathrm{v}$ njem.

\section{SAMOSTOJNOST}

Pomemben del vsakega učnega procesa je, da se posameznik nauči učiti se. Ta vidik učnega procesa je $\mathrm{v}$ institucionaliziranih oblikah izobraževanja še precej zanemarjen. V nasprotju s to prakso pa učna pogodba že zaradi samega načina nastajanja in kasnejšega izpolnjevanja spodbuja posameznika, da prevzame odgovornost za lasten študij in postane samostojen ter manj odvisen od napotkov in navodil drugih. Spodbujanje samostojnosti je tudi ključna naloga organizacij pri povečevanju učinkovitosti zaposlenih. Kako učna pogodba spodbuja samostojnost? Tako, da omogoča dokaj svobodno izbiro glede tega, kaj in predvsem kako bodo študirali. Posamezniku daje aktivno vlogo $v$ celotnem učnem procesu, od postavljanja ciljev do oblikovanja učnih strategij in navsezadnje mu ponuja sodelovanje tudi pri ovrednotenju in preverjanju rezultatov ter dokazov izpolnjevanja učne pogodbe.

Poleg vsebinskega znanja/konkretne spretnosti, ki mu je učna pogodba namenjena, posameznik razvije tudi veliko splošnih spretnosti na področjih, kot so določanje ciljev, komunikacija in pogajanje, projektno načrtovanje in projektna evalvacija. To so poklicna znanja, pomembna na vseh področjih poslovne prakse. Prav tako učna
Posamezniki, ki uporabljajo učno pogodbo, sčasoma postanejo vse bolj neodvisni od svetovalcev in so sposobnejši prepoznavati svoje učne potrebe tudi po končanem programu, ki je tekel po načelih učne pogodbe. Veliko bolje razumejo naravo učenja, svoj lastni uěni stil, naučijo se premišljeno odločati, kakšne učne strategije bi jim najbolj ustrezale, katere so njihove najljubše metode. Proces pogajanja in izpolnjevanja uěne pogodbe jih spodbudi, da refleksivno razmisljajo o svojem učenju in praktični uporabi pridobljenega znanja. Učna pogodba torej spodbuja refleksivne pristope $\mathrm{k}$ učenju, ki so se v praksi izkazali za najučinkovitejše.

pogodba spodbuja iskanje po različnih virih informacij in rabo alternativnih pristopov $\mathrm{k}$ reševanju problemov ne le za namene učne pogodbe, temveč tudi kasneje pri reševanju delovnih problemov.

Svetovalci postanejo študijski partnerji svojih študentov. Tak odnos je potencialno demokratičnejši kakor tradicionalna povezava med svetovalcem in posameznikom. V tem procesu se bogati Posameznik z učno pogodbo prevzame odgovornost za ucenje. tudi svetovalec. Rezultat učne pogodbe so novo znanje in novi pogledi za obe strani.

\section{STRUKTURIRANJE UČNE DEJAVNOSTI}

Učna pogodba ponuja formalen okvir, znotraj katerega lahko strukturiramo učne dejavnosti. $\mathrm{O}$ ustreznih učnih ciljih in strategijah se pogajamo nenazadnje zato, da bi posameznik izostril žarišče svojega programa in si zastavil jasne cilje in smernice delovanja. S skupno in vnaprejšnjo opredelitvijo učnega načrta, rezultatov in ocenjevalnih kriterijev imajo lahko vsi vpleteni (posameznik, svetovalec, insti- 


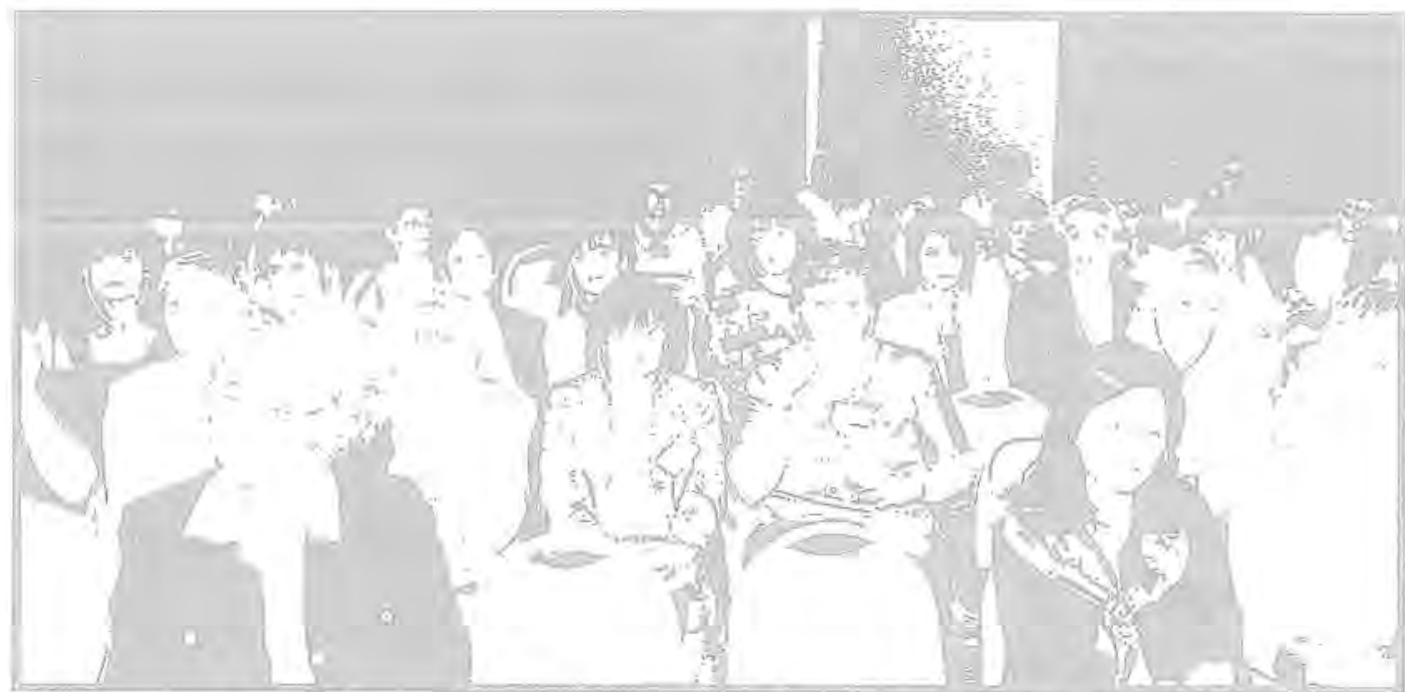

tucija, delodajalci) podobna pričakovanja glede učnega projekta. Učna pogodba predstavlja torej učinkovito sredstvo za dosego enotnih ciljev, s čimer preprečujemo pogosta nestrinjanja in še pogostejše napačne interpretacije, ki se lahko pojavijo pri določanju ciljev v tradicionalnem izobraževanju.

Obenem učna pogodba zaradi svoje prilagodljivosti omogoča tudi veliko prožnosti tako posamezniku kakor tudi svetovalcu, in to ves čas učnega procesa.

\section{NEPRISTRANSKOST}

Učna pogodba krepi zavedanje o drugačnosti. Vsak posameznik, ki vstopa $\mathrm{v}$ izobraževalni proces, ima svoje potrebe, svoje vrednote, svoj učni stil, svojo osebno izobraževalno biografijo. $\mathrm{V}$ učni pogodbi lahko le $\mathrm{z}$ malce spretnosti posameznikove posebne potrebe in morebitne kulturne razlike prikrojimo posameznim vrednotam. Učna pogodba organizacijam in izobraževalnim institucijam, svetovalcem in delodajalcem omogoča, da se odzivajo na raznovrstne potrebe posameznikov in na situacije, $v$ katerih ti delujejo, ter tako povečujejo dostopnost in nepristranskost izobraževalnega programa. Uporaba učne pogodbe je odlična tudi za vse tiste, ki zaradi katerega koli razloga ne morejo obiskovati rednih/organiziranih izobraževalnih srečanj/ predavanj.

\section{SKLEPNE MISLI}

Vsi ves čas iščemo načine in poti, kako narediti izobraževanje učinkovitejše. V ta namen smo iznašli kar nekaj čarobnih formul in inovativnih pristopov, ki pa vsi po vrsti nastopijo šele po končanem usposabljanju oz. izobraževanju. Če želimo biti resnično učinkoviti, moramo merjenje učinkovitosti vtkati $v$ sam proces izobraževanja in začeti z merjenjem že na začetku. Učna pogodba je zagotovo orodje, ki že v svoji filozofiji vključuje merjenje učinkovitosti izobraževanja. In ne le to. Hkrati odgovarja in zadosti vsem potrebam izobraževanja odraslih. Naslavlja namreč njihovo predstavo o sebi, identiteto, samostojnost, bogastvo izkušenj. Prav tako pa ustreza tudi vsem novodobnim pristopom $\mathrm{k}$ učenju, kot je učenje na daljavo oz. "on-line" učenje. V organizacijah omogoča vzpostavitev tako imenovane psihološke pogodbe, saj je učna pogodba vselej rezultat pogajanj med učečim se posameznikom in delovno organizacijo. Potemtakem predstavlja tudi vabljivo kadrovsko orodje za 
pritegnitev talentov. Vsestranska uporabnost in relativno nezahtevna izpeljava postavljata uěno pogodbo $\mathrm{v}$ središče priljubljenosti učečega posameznika pa tja, kjer bi že vselej moral biti: $v$ samo središče učnega procesa.

\section{LITERATURA}

Alliger, G. M. and Janak, E. A. (1989). Kirkpatrick's Levels of Training Criteria: Thirty Years Later. Personnel Psychology, 42, str. 331-340.

Argyris, C. (1964). Integrating the Individual and the Organization. New York: John Wiley and Sons.

Argyris, C., Schon, D. (1978). Organizational Learning: A Theory of Action Perspective.

Bandura, A. (1977). Social Learning Theory. Englewood Cliffs, N. J.: Prentice-Hall.

Bischoff, L. L. (1969). Adult Psychology. New York: Harper and Row.

Boak, G., Stephenson, M. (1987a). Management learning contracts: from theory to practice: Part 1 Theory. Journal of European Industrial Training, 11, 4, str. 4-6.

Boak, G., Stephenson, M. (1987b). Management learning contracts: from theory to practice: Part 2 Practice. Journal of European Industrial Training, 11, 6, str. 17-20.

Borich, G. D. (ur.) (1974). Evaluating Educational Programs and Products. Englewood Cliffs, N. J.: Educational Technology Publications.

Botkin, J. W., Elmandjra, M., Salitza, M. (1979). No Limits to Learning. A Report to the Club of Rome. New York: Pergamon Press.

Boud, D. (1988). Moving towards autonomy. V Boud, D. (ur.), Developing Student Autonomy in Learning, 2 . izdaja. London: Kogan Page, str. 17-39.

Boud, D. (1992). The use of self-assessment schedules in negotiating learning. Studies in Higher Education, 17, 2, str. 185-200.

Brečko, D. (1998). Kako se odrasli spreminjamo, Didakta.

Brečko, D. (2002). Štirideset sodobnih učnih metod, Sofos.

Brečko, D. (2002). Izobraževalni management 2002 TOP 10 primerjalna raziskava. GV Izobraževanje.

Brookfield, S. D. (1987). Developing Critical Thinkers. San Francisco: Jossey-Bass.

Brookfield, S. D. (1986). Understanding and Facilitating
Adult Learning, San Francisco; Jossey-Bass.

Brookfield, S. D. (1988). Conceptual, Methodological and Practical Ambiguities in Self-Directed Learning. Self-Directed Learning: Application and Theory. H. B. Long (ur.). Athens: GA University of Georgia Press.

Caffarella, R. S., O'Donnell, J. M. (1991). Judging the quality of work-related, self-directed learning. Adult Education Quarterly, 42, 1, str. 17-29.

Candy, P. (1991). Self-Direction for Life-Long Learning: A Comprehensive Guide to Theory and Practice. San Francisco, CA: Jossey-Bass.

Cascio, W. F. (1987). Costing Human Resources; The Financial Impact of Behavior in Organizations. 2. izdaja. Boston, MA: Kent.

Cross, V. (1992). Using Learning Contracts in Clinical Education. Birmingham: Queen Elizabeth School of Physiotheraphy.

Hansen, A. (1991). Establishing a teaching/learning contract, V Christensen, C. R., Garvin, D. A., Sweet, A. (ur.), Education for Judgement: The Artistry of Discussion Leadership. Cambridge, Mass.: Harvard Business School Press, str. 123-135.

Higgs, J. (1988). Planning learning experiences to promote autonomous learning. V Boud, D. (ur.), Developing Student Autonomy in Learning, 2. izdaja. London: Kogan Page, str. 40-58.

Holton, E. F. (1998). Performance Domains: Bounding the Theory and Practice. V Swanson, R. (ur. zbirke), Torraco, R. (ur. let.), Advances in Developing Human Resources. Washington, D. C.: ISPI Press.

Knowles, M. S. (1975). Self-Directed Learning: A Guide for Learners and Teachers. New York: Association Press.

Knowles, M. S. (1990). The Adult Learner: A Neglected Species, 4, izdaja. Houston, Tex: Gulf Publishing.

Knowles, M, S. (1980). The Modern Practice of Adult Education: From Pedagogy to Andragogy. Englewood Cliffs: Cambridge.

Kolb, D. A. (1984). Experiental Learning: Experience as the Source of Learning and Development. EnglewoodCliffs: Prentice-Hall.

Kolb, D. A. (1981). Experiential Learning Theory and the Learning Style Inventory: A Reply to Freedman and Stumpf. Academy of Management Review, 6, str. 289-296.

Kolb, D. A. (1976). The Learning Style Inventory. Boston: McBer.

Marton, F, Hounsell, D., Entwistle, N. (ur.) (1984). The Experience of Learning. Edinburgh: Scottish Academic Press. 
McLagan, P. A. (1989). Models for HRD Practice. Training and Development, 43 (9), str. 49-59.

Rosenblum, S., Darkenwald, G. G, (1983). Effects of Adult Learner Participation in Course Planning on Achievement and Satisfaction. Adult Education Journal, 20 (2), str. 67-87.

Russell, A. L., Creedy, D., Davis, J, (1994). The use of contract learning in PBL. V Chen, S. E., Cowdroy, R. M., Kingsland, A. J., Ostwald, M. J. (ur.), Reflections on Problem Based Learning. Campbelltown, NSW, Australia; Problem Based Learning Network.

Sampson, J., Anderson, G., Boud, D. (1992). Participating in educational decisions: students' experience of the use of learning contracts. V Adult Education for a Democratic Culture. Papers from the 32nd National Conference of the Australian Association of Adult and Community Education, Canberra, AAACE, str. 1-10.

Sampson, J., Anderson, G., Boud, D. (1993). Engaging with diversity: using learning contracts to link the needs of students, work and academic programs. Research and Development in Higher Education, 16, str. 311-316.

Smith, R. M. (1983). Learning How to Learn: Applied Theory for Adults, Buckingham: Open Uniyersity Press.

Swanson, R. A. (1995). Human Resource Development: Performance is Key. Human Resource Development Quarterly, 6 (2), str. 207-213.

Swanson, R. A., Fentress, J. (1975). The Effects Influential Tactics on Instructor Ratings, Journal of Industrial Teacher Education, 13 (1), str. 5-16.

Swanson, R. A., Holton, E. F. (1997). Human Resource Development Handbook: Linking Research and Practice, San Francisco: Berrett-Koehler.

Tough, A. (1979). The Adults' Learning Projects: A Fresh Approach to Theory and Practice in Adult Education, Toronto: Ontario Institute for Studies in Education. 